\title{
Chapter 10 \\ Conservation and Sustainable Utilization of the Fiji Sago Palm Metroxylon vitiense
}

\author{
Dick Watling
}

\begin{abstract}
The Fiji sago palm is an endemic palm with a restricted and declining population, whose long-term survival is threatened by habitat loss and unsustainable harvesting for thatch and heart of palm. NatureFiji-MareqetiViti, a Fijian conservation organization, initiated a campaign in 2007 to highlight its endangered status and to stimulate the introduction of conservation management measures. After widespread consultation with the landowners of the remaining sago stands, users, government and administrative agencies, and other stakeholders, a 2010 2015 Species Recovery Plan was endorsed by the government and became the foundation for implementation activities. The plan is currently being reviewed with a view to the preparation of a successor. This paper reviews the successes and failures of the past 5 years of implementation. Despite some notable successes, given the seriousness of the decline of the Fiji sago palm, the achievements can be viewed as mixed, while overall progress has been an insufficient response in the circumstances. In part, this is probably because the project is not owned or mainstreamed by the government (which has not contributed funding); the administrative energy still remains with NatureFiji-MareqetiViti which has difficulties in resourcing a program with the necessary continuity.
\end{abstract}

\subsection{Introduction}

The Fiji sago palm Metroxylon vitiense is endemic to Fiji where it has been recorded from the islands of Viti Levu, Vanua Levu, and Ovalau. Pollen analysis in sediment cores from a variety of swamp sites on Viti Levu and Vanua Levu confirms that the species was once much more widely distributed than at present (Hope et al. 2009). Today it has a remnant distribution and is declining on Viti Levu. Only one population is known from Vanua Levu and this may be introduced (Watling 2005). The remaining natural stands are found in lowland freshwater swamp sites, although the

\footnotetext{
D. Watling $(\bowtie)$

NatureFiji-MareqetiViti, Suva, Fiji

e-mail: watling@naturefiji.org
} 
Upper Navua River Conservation Area stand is an exception being in a mixed lowland forest setting.

Another species of sago, Metroxylon warburgii, is found on the northern Fijian island of Rotuma and has been introduced to a few places on Viti Levu and Vanua Levu.

The Fiji sago palm never produces suckers, and the only confirmed growing period to flowering is 24 years for two palms (Watling pers. obs.) which may be the longest growth interval for any species of sago.

Concern at the decline of the Fiji sago palm was first raised in Fiji's first State of the Environment Report in 1992 (Watling and Chape 1992). Unlike Fiji's other native palms, it was not listed in Fiji's Endangered and Protected Species Act 2002, and it was not until research was conducted in 2006-2007 which confirmed that it is seriously threatened (Rounds 2007). Thereafter, NatureFiji-MareqetiViti (NFMV), a local conservation organization, instigated a campaign to highlight its endangered status and to stimulate the introduction of conservation management measures.

Because of its restricted distribution, aspects of its biology, and threats from habitat destruction and harvesting, the Fiji sago palm has been classified as endangered under IUCN Red List criteria; it may in fact be critically endangered. However, there has been no rush to have it officially categorized by IUCN until such time as conservation measures workable in the Fijian context are successful. Initially, NFMV conducted wide-ranging field surveys and consultation with landowners, harvesters, and users (for thatch and heart of palm) which enabled the production of a Species Recovery Plan for the Fiji sago palm. This plan has been endorsed by the Fiji Government and has been the basis of ongoing conservation and sustainable utilization efforts.

\subsection{Population Status of the Fiji Sago Palm}

Fifteen single-species stands of Fiji sago palm (of 1 ha or more) are known with a combined original area of approximately 450 ha. All but one of the significant sites are within the provinces of Namosi and Serua in southern Viti Levu (Fig. 10.1). Only one of these, at Nukusere, Namosi ( 15 ha), is considered safe because of its inaccessibility. Culanuku ( 10 ha) has been restored by the local community with NFMV assistance and with continued community support will survive. Another approximately 450 ha of sago is mixed with native forest and mahogany plantation on the banks of the Navua River in the vicinity of Upper Navua gorge, much of which are within the Upper Navua Conservation Area (Fiji's first and sole Ramsar Site). This population is receiving active conservation attention from Rivers Fiji Ltd., a rafting tourism company operating in the Navua Gorge.

The others need a range of management interventions from cessation of harvesting to intensive weed removal and drainage reversal for them to survive (NFMV 2010; Morrison et al. 2012). 

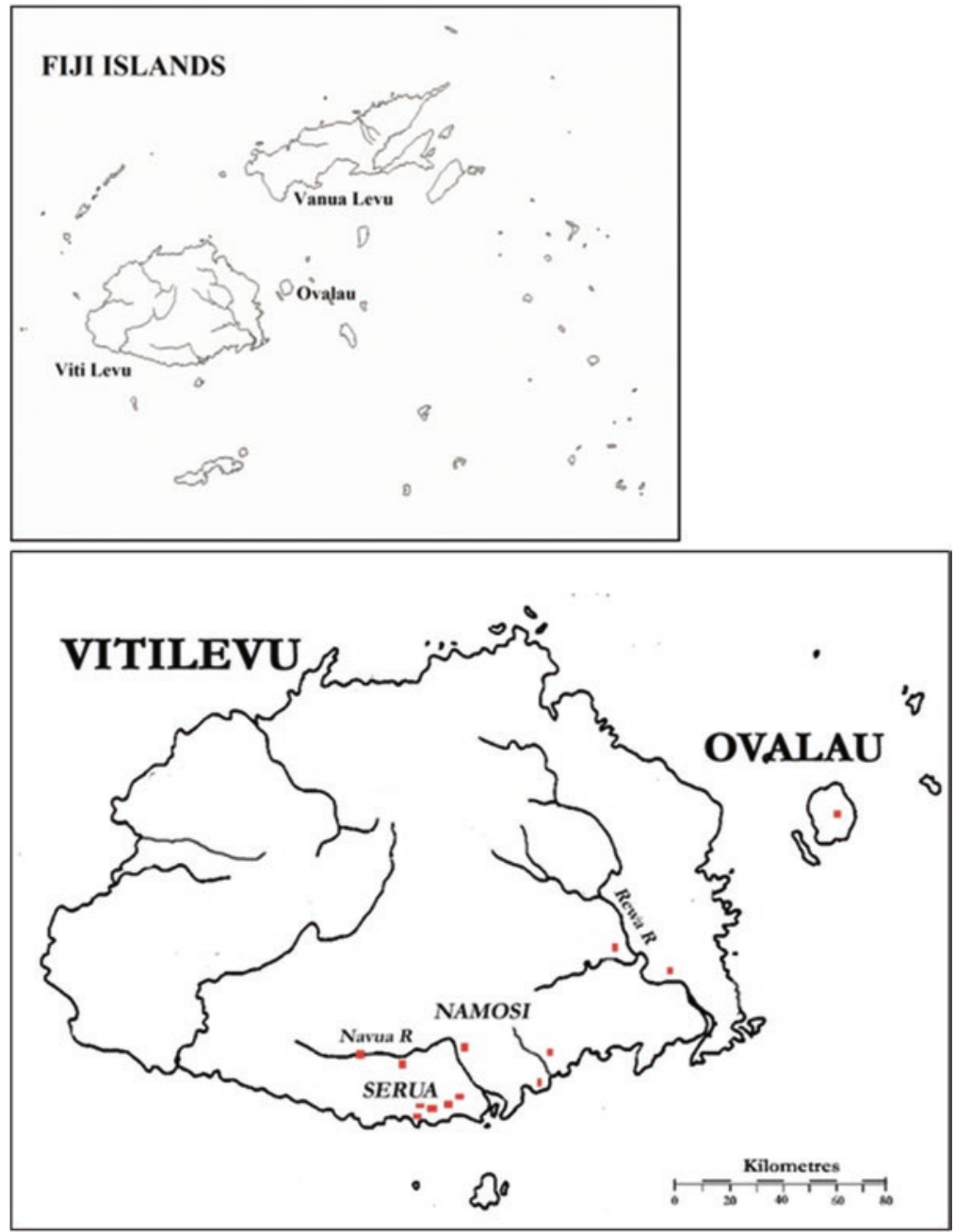

Fig. 10.1 Fiji Islands (upper) and location of remaining Fiji sago palm stands on Viti Levu and Ovalau

\subsection{Cultural Use of the Fiji Sago Palm}

In 1860-1861, Berthold Seemann in his travels through Serua and Namosi provinces probably collected and subsequently described the Fiji sago palm Metroxylon vitiense. He made no mention of Fijians using sago for any purpose; however, he was clearly impressed by the abundance of sago palms which he described as: “... fine groves, several miles in extant were seen by us on various branches and deltas of the Navua River" (Seemann 1862). 
The various species of Metroxylon have important cultural values wherever they occur in the Pacific islands and SE Asia. The two primary uses are for the production of edible starch from the stem and durable leaf thatch. Of all the Pacific islands where Metroxylon are found, Fijians appear to have made least use of sago palms. Except in Rotuma where $M$. warburgii occurs, there is no record of Fijians ever eating sago, even as a famine food. The Rotuman language has at least 25 words which relate to the cultural use of their sago (McClatchey and Cox 1992), while the Fijian language has none; even the original Fijian name for the sago palm is uncertain. The absence of any linguistic association with sago palm or its use has led to linguists wondering if it is not an introduced species (P. Geraghty pers. comm), something it clearly is not.

Although some Fijian communities used sago extensively as thatching material during the twentieth century, it is quite likely that its use as such was learned from Solomon islanders in Fiji, as indeed the people of Deuba explicitly told the anthropologist Geddes during his stay at Deuba village, from 1942 to 1943. Geddes relates that "... the use of the leaf itself is comparatively recent, having been learnt from indentured Solomon islanders..." (Geddes 2000). Currently, sago palm is rarely if ever used for thatching materials for Fijian houses, because it is very labor intensive and because of the increased use of corrugated iron as a roofing material.

Unlike the use of sago species in Vanuatu, Rotuma, Samoa, and Solomons ( $M$. warburgii, M. paulcoxii, and $M$. salomonense) which remains an integral part of the traditional agricultural system, this is not the case with $M$. vitiense in Fiji. The rural communities of Vanuatu, Rotuma, Samoa, and Solomons habitually practice traditional agriculture, and, where used for leaf thatch, there is good practical knowledge of its sustainable use for this purpose. What use is made of sago in Fiji is from wildgrown-natural stands of Fiji sago palm with only quasi-cultural sustainable use practices.

The lack of a cultural connection to sago in Fiji has significant repercussions for its conservation management.

\subsection{Causes of Decline and Current Threats}

The causes of decline and current threats of the Fiji sago palm are described in detail elsewhere (NFMV 2012; Morrison et al. 2012); they are summarized here:

1. Biology. Fiji sago palm does not produce suckers and reproduces only through a single fruiting before it dies. It may also have the longest period of growth - germinating seed to mature fruit of 25 years or more. Such a life history renders it vulnerable to catastrophic events - cyclones, new pests, new human uses, etc. Vulnerability increases as the stand size decreases.

2. Drainage for agriculture and land use needs. Ongoing, presumably since the first arrival of humans to Fiji, but recently subject to increased agricultural land needs, as well as residential subdivisions in key sago habitats, such as Pacific Harbour (Fig. 10.2). 


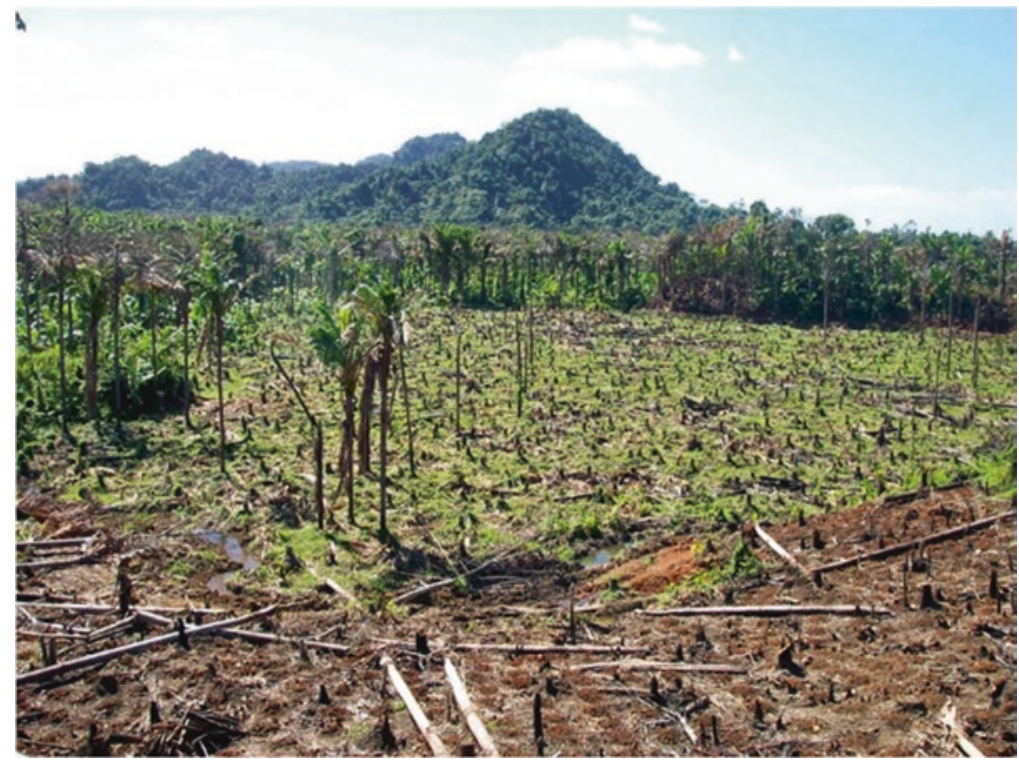

Fig. 10.2 Dakunikoro, the world's largest stand of Fiji sago palm: drained and subdivided for agriculture (Photo: NFMV)

3. Harvesting for thatch. Historically insignificant, there was a sudden and dramatic increase in the demand for sago palm thatch from the tourism industry to provide a traditional bure hut look (Fig. 10.3), 2000-2010. Originally, Fijians may have developed or adopted sustainable thatch harvesting techniques, but the attraction of major cash income for sago palm shingles from the tourist industry resulted in large areas of sago palm being felled using chain saws so that leaves could be easily removed.

4. Palm heart trade. In 2008 , at least 200 palms were felled per week to cater to palm heart consumers. This number would increase up to 250 trees during special religious or cultural events rendered important for Indo-Fijians (NFMV 2008a; Fig. 10.4).

5. Invasive weeds. Excessive leaf removal and/or felling for thatching (and the palm heart trade) opens up the canopy of Fiji sago palm stands and introduces a serious threat of weed invasion by the exotic vines Merremia peltata, Mikania micrantha, and other creepers which can smother young palms and even kill adults before they fruit. Regenerating palms are attractive to wandering cattle and susceptible to grazing causing death. 


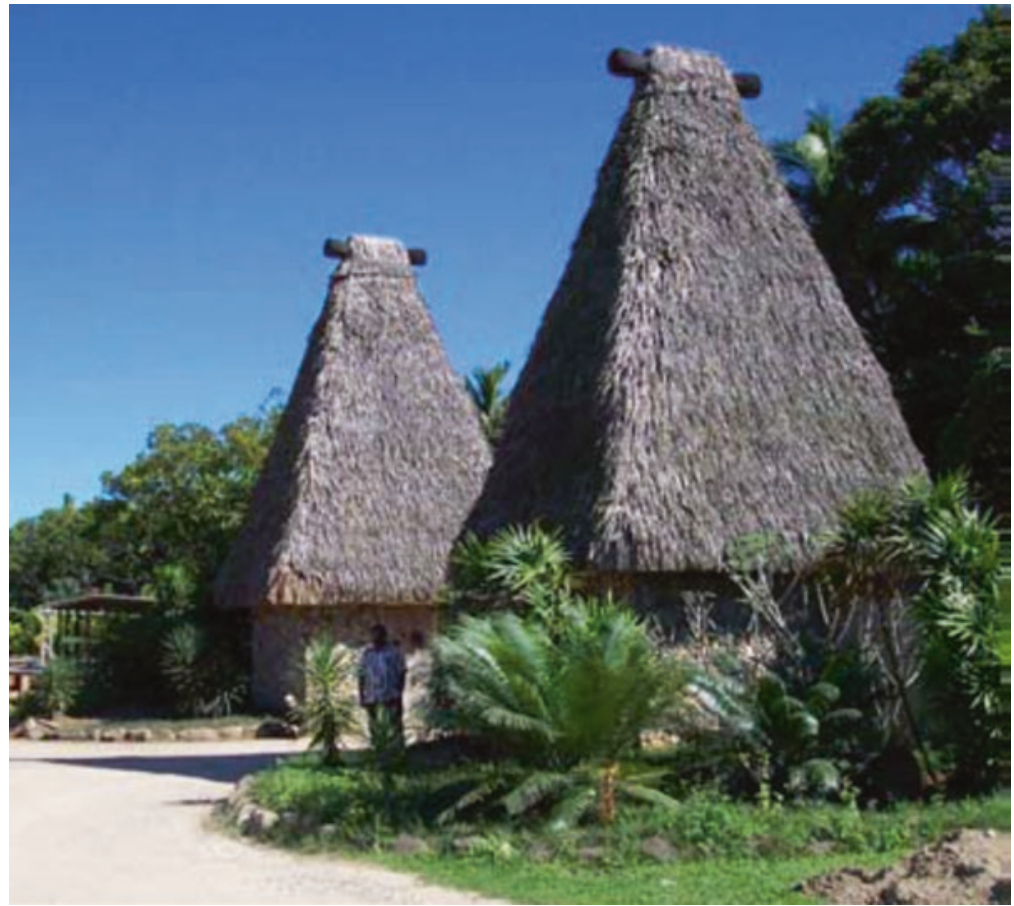

Fig. 10.3 Use of Fiji sago palm thatch in the tourism industry (Photo: NFMV)

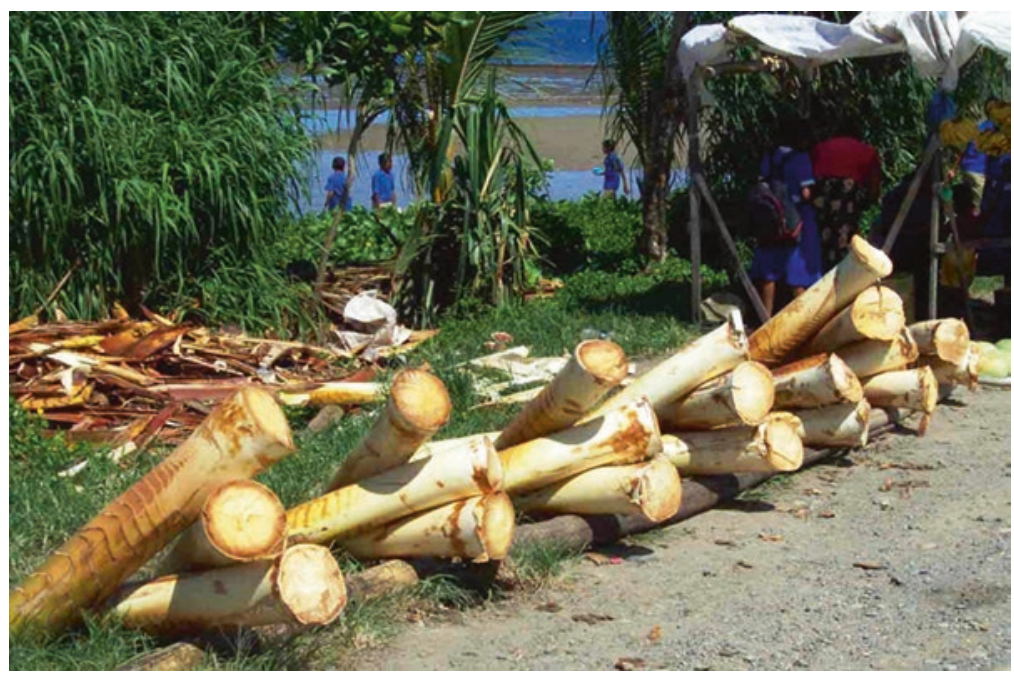

Fig. 10.4 Fiji sago palm heart for sale - 2010 (Photo: NFMV) 


\subsection{Conservation Management of the Fiji Sago Palm}

Soon after its establishment in 2007, NFMV selected the Fiji sago palm as one of its flagship conservation campaigns identifying it as an unknown national priority completely overlooked by government and the big international conservation NGOs (BINGOs). NFMV saw the need, which is even more pressing today, for local priorities to be identified and championed in the face of a lack of government expertise and resources and well-funded campaigns for species of international interest which form the core of the BINGO agenda in small countries. Since the start, NFMV has provided all the energy to advance management initiatives, generated almost all the funding, and developed or co-opted the necessary expertise.

Initially, NFMV undertook wide-ranging field surveys and consultation with landowners, harvesters, users (thatch and heart of palm), and government, and the National Trust of Fiji set up a multi-agency Sago Palm Recovery Plan Committee which had representatives from all major stakeholders. Through this committee, The Fiji Sago Palm Species Recovery Plan (2010-2015) was drawn up and endorsed by the government's Department of Environment in June 2010 (NFMV 2010).

The most challenging issue which emerged, as knowledge of the Fiji sago palm, its status, and utilization was gained, revolved around the fundamental conservation approach which the recovery plan should adopt. Should there be a push for international listing as an endangered or critically endangered species, inclusion on Fiji's Endangered and Protected Species Act, a ban on commercial use, strict protection, and priority identification of sago-protected areas? Alternatively, were the conditions in Fiji less conducive to a top-down legislative/administrative approach and more conducive to a controlled stimulation of the market for thatch using sustainable harvesting methods, such that the landowners would become interested in maintaining the sago stands for their own commercial benefit? Landowners in Fiji are extremely powerful in respect of the resources on their land, and NFMV with the Sago Palm Recovery Plan Committee opted for the latter approach in the Recovery Plan.

The management recommendations in the recovery plan are categorized into five main groups as summarized below.

1. Public Awareness/Working with Communities

The priorities here were to work with the following stakeholders:

- Landowning communities - to assist them to understand the commercial elements of the sago palm thatch industry, to take control out of the hands of middlemen, to set up an association of sago palm landowners, and to develop and have accepted sustainable harvesting guidelines (NFMV 2008b) and sago restoration guidelines.

- Provincial authorities - ensuring that the provincial authorities understand the potential rural economy gains from a sustainably harvested sago thatch industry as well as the alternative: its inevitable demise and the loss of cash benefitting an underdeveloped rural economy calculated at USD 1.5 million in 2009. 
- Freehold landowners - some of the remaining Fiji sago palm stands are on freehold land (land which is owned by individuals or corporate bodies). Initiatives were envisaged to introduce protection and restoration and additional planting of stands.

\section{Fiji Sago Palm Users}

- Thatch users: the tourism industry - to instigate a change in behavior in the use of sago palm thatch by tourism users, through direct contact, presentations, and distribution of quality awareness material. Promotion of the opportunity to engage in a meaningful green and socially beneficial industry through the use of only sustainably harvested thatch.

- Thatch users: architects - as an in vogue artifact of pseudo-cultural reference used in tourism projects, ensure that the architects are fully aware of what they are promoting and to cooperate in educating clients on the sustainability issues relating to the use of palm thatch.

- Palm heart users - the sago palm heart trade was identified as a serious contributor to the decline of accessible sago palm populations. The phasing out of the trade was identified in the Recovery Plan, but the mechanism remained to be agreed upon. An alternative palm heart source from a species which could be harvested sustainably was to be sought (Fig. 10.5).

3. Conservation Actions

- Prioritizing populations - given the great variation in the status of the remaining sago palm stands, there was a need to prioritize management actions based on an in-depth and up-to-date survey of the remaining stands.

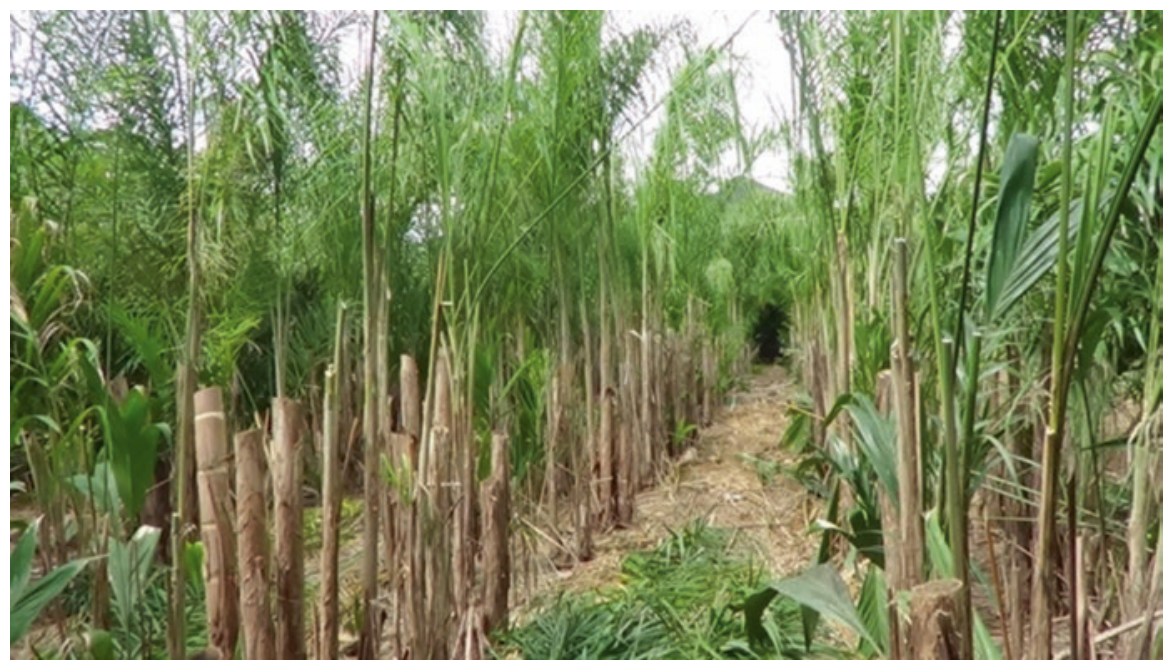

Fig. 10.5 Fiji sago heart of palm substitute - peach palm (Bactris gasipaes) after the third successive annual stem harvest -5 years after planting (Photo: NFMV) 
- Additional sites - surveys are still required for reported but unvisited sites and enquiries to locate any unregistered sites.

- Threat analyses - more in-depth discussion with sago palm landowners, especially the larger stands with a view to understanding current threats and the conservation management approaches most suitable and/or favorable with the landowners, for the particular sites.

- Ex situ populations - given the precarious nature of the majority of the existing sago stands, naturalized ex situ stands are an important conservation strategy and should be used to maintain the genetic diversity of the species (Fig. 10.6).

- Development of guidelines - guidelines required for sustainable harvesting, restoration of degraded Fiji sago palm stands, and the establishment of ex situ stands.

4. Update Threatened Status Listing of Fiji Sago Palm

The priorities here were:

- To include the Fiji sago palm in Fiji's Endangered and Protected Species Act

- Have it recognized as a non-timber forest product under the Forestry Decree 1992

- To liaise with IUCN in respect of the IUCN Red List.

5. Research

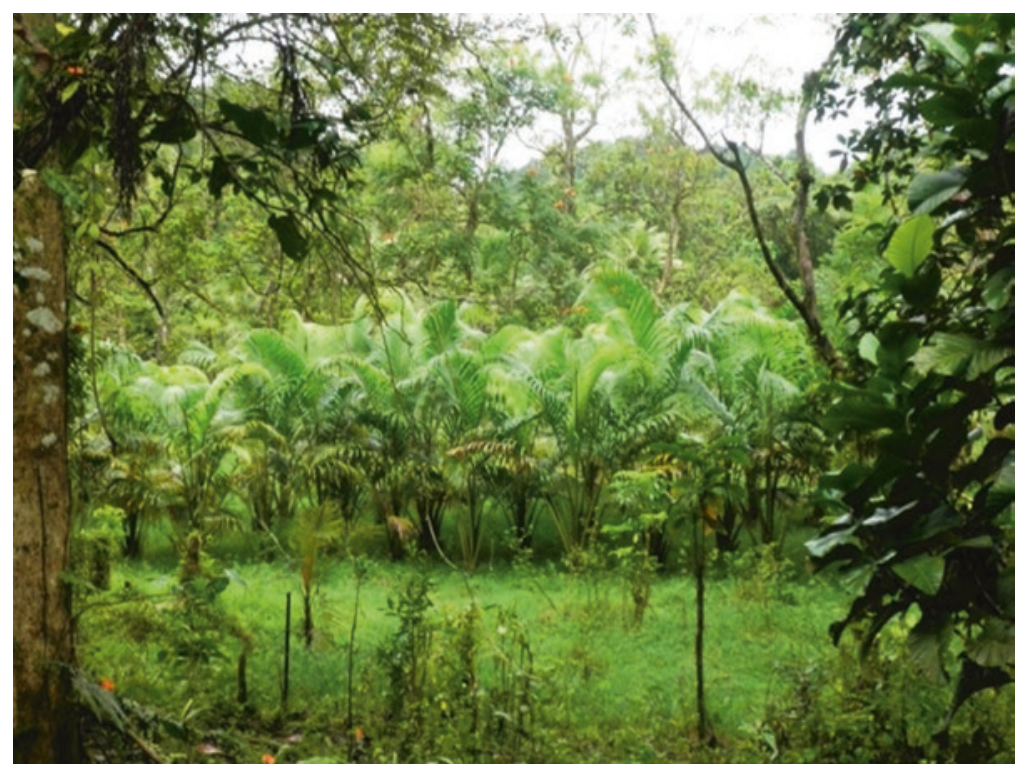

Fig. 10.6 Ex situ planting of Fiji Sago Palm in the Garrick Forest Reserve, Navua planted by NatureFiji-MareqetiViti members 
- Genetic variation - the Fiji sago palm is currently fragmented into at least 15 stands, with only one stand each on Vanua Levu and Ovalau. Maintaining diversity within the species is clearly important for its survival.

- Invasive species - small stands of Fiji sago palm are susceptible to invasion by a variety of aggressive alien species. The vines Merremia peltata and Mikania micrantha are particularly aggressive, while the naturalized pond apple Annona glabra can be a serious threat. How to deal with these requires restoration work experience trialing different techniques.

- Ecosystem value - given the former abundance of the Fiji sago palm especially in coastal areas behind the mangrove and its tolerance of saline inundation, it may have potential in developing climate change adaptation measures. Currently we do not fully understand the role that the palm plays in its ecosystem at natural levels of abundance and ecosystem composition (predators, dispersal, pollinators, etc.). Given its former abundance, this role may be substantial. A detailed study of its synecology was identified as being important including the variation in the current natural populations.

\subsection{Conservation Management: Achievements and Lessons Learned from the First 5 Years}

The first 5-year Fiji Sago Palm Species Recovery Plan (2010-2015 NFMV 2010) is currently being reviewed with the intention of producing another 5-year plan building on the achievements and lessons learned. Currently NFMV is seeking the resources to initiate a comprehensive review with all stakeholders.

Table 10.1 provides a summary of outcomes of the recovery plan during its 5-year implementation period.

Notable achievements include:

- Increased awareness and control of thatch harvesting by the majority of landowners. Sustainable harvesting guidelines are now widely, but not universally, agreed with and adopted.

- Active involvement by provincial offices.

- Fiji Sago Palm Species Recovery Plan agreed upon by all stakeholders and endorsed by the Department of Environment.

- Forestry department implementing requirements of the Forests Decree 1992 and Endangered and Protected Species Act.

- Introduction of peach palm (Bactris gasipaes) as a sustainable alternative for sago palm heart trade with first seedlings provided to Ministry of Agriculture for bulking up and distribution.

- Successful restoration of 10 ha Culanuku sago palm stand (Fig. 10.7).

- Successful ex situ planting in the Garrick Forest Park. 


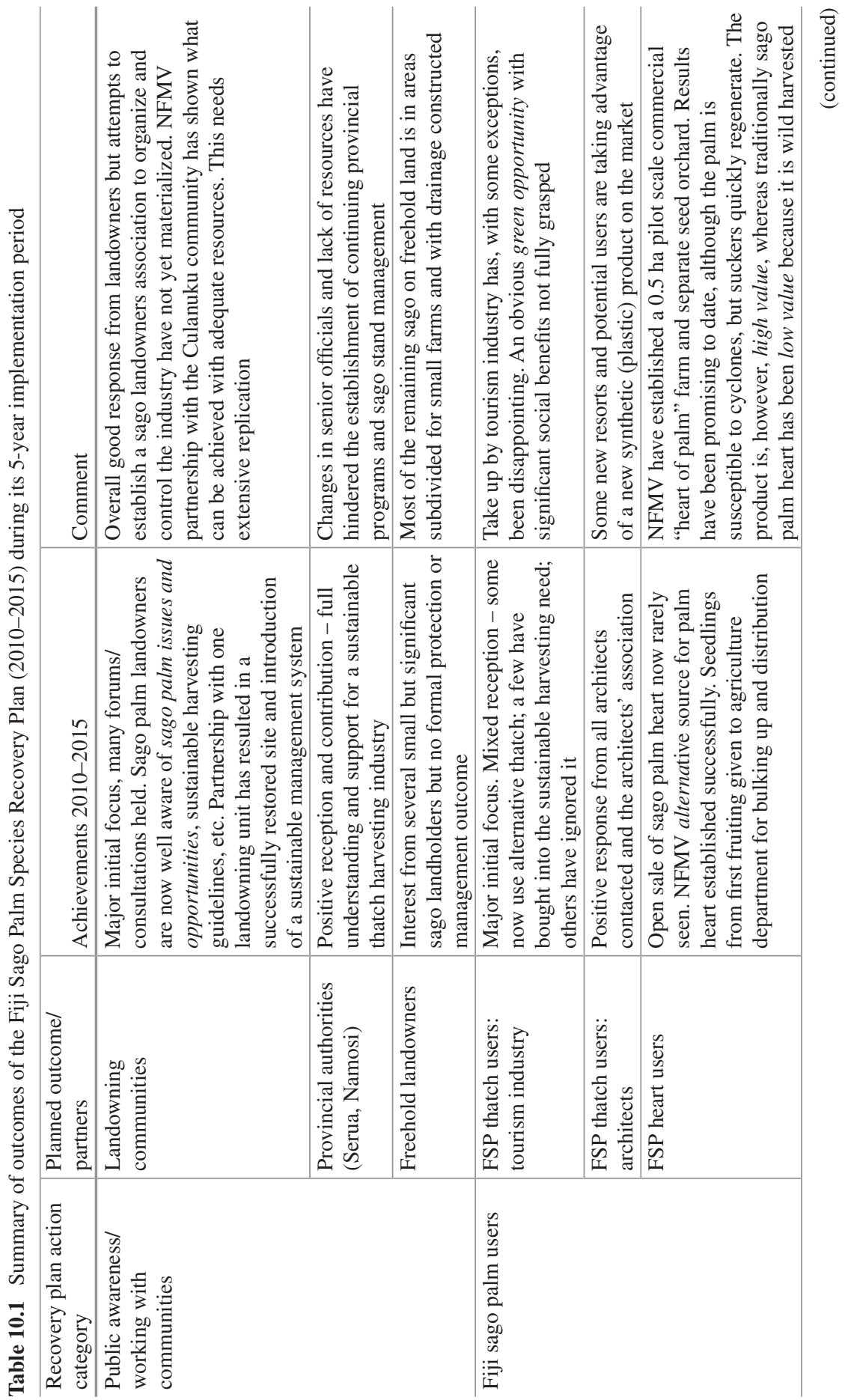




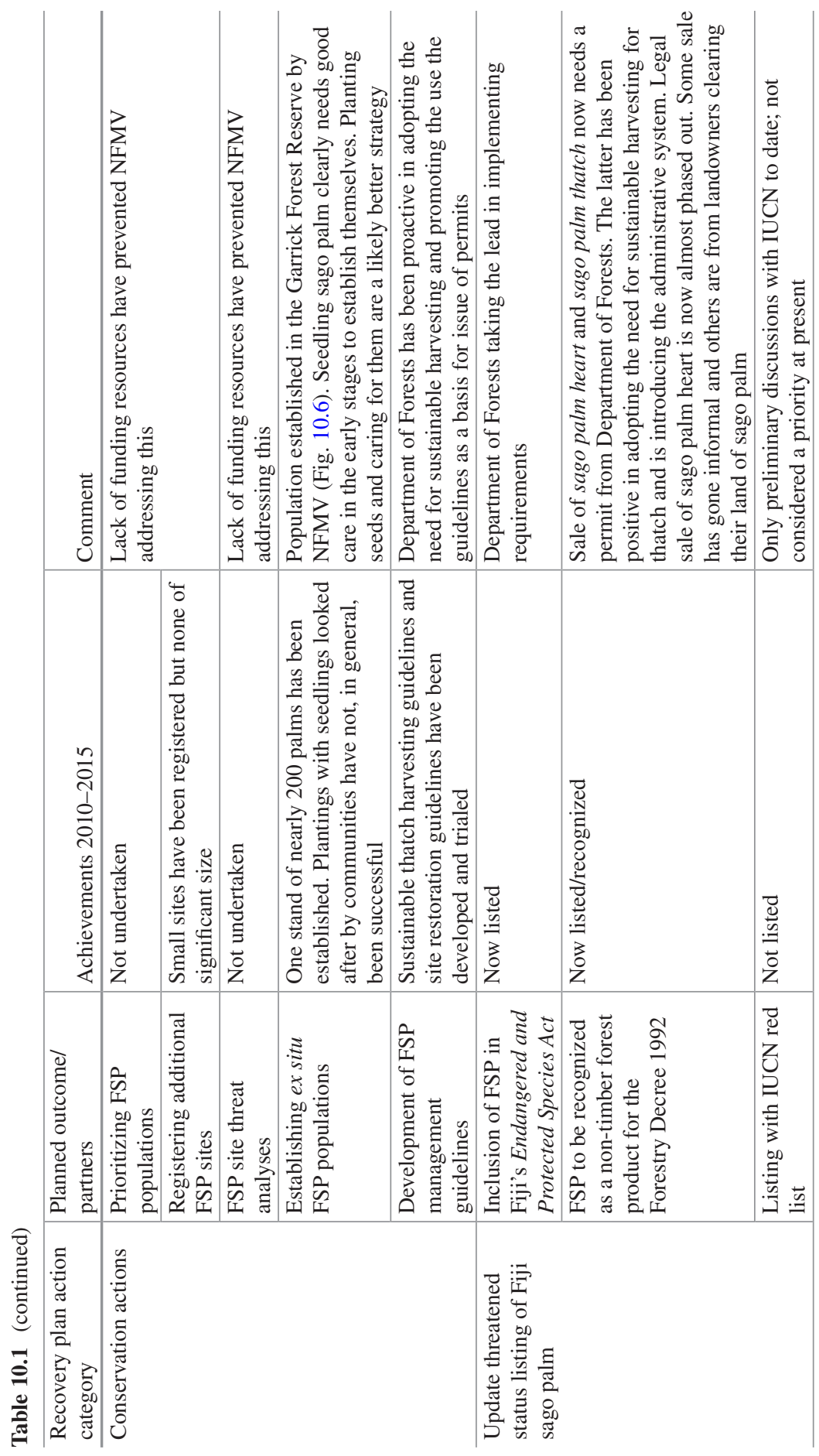




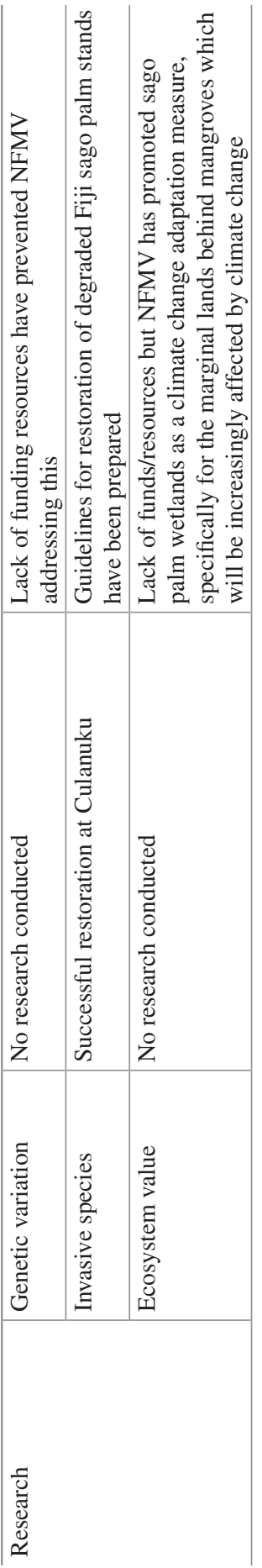




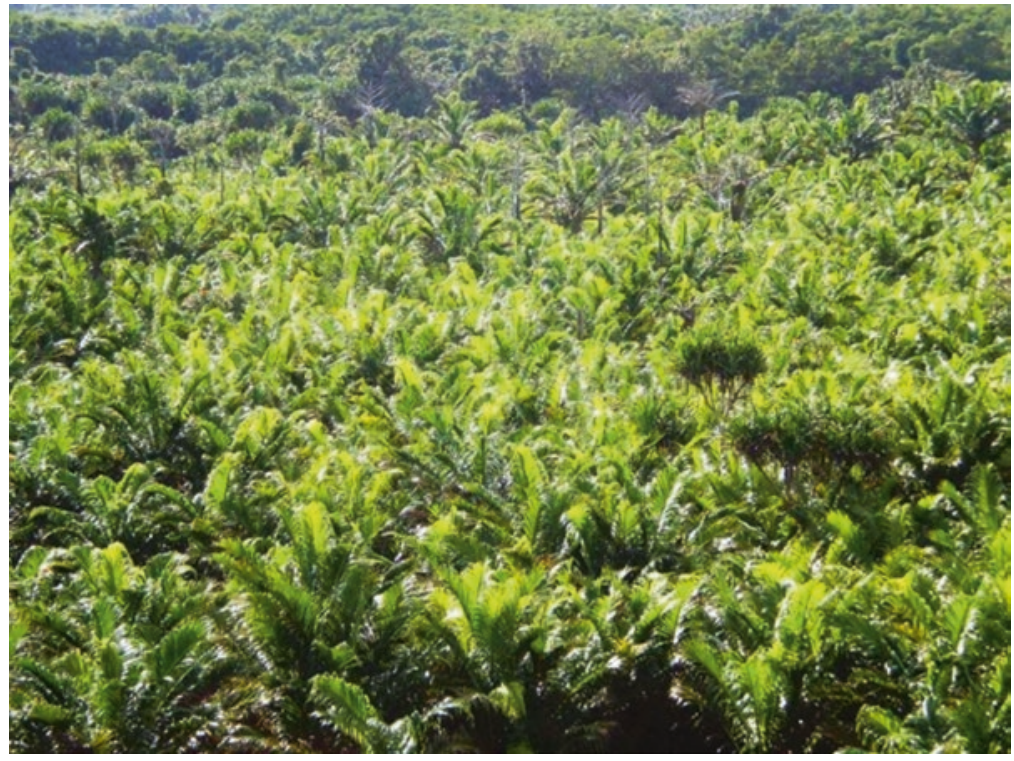

Fig. 10.7 The Culanuku community Fiji Sago Palm stand which has been sucessfully restored with the removal of invasive creepers and replanting

In conclusion, despite some notable successes, given the seriousness of the decline of the Fiji sago palm, the achievements can been viewed as mixed, while overall progress has been an insufficient response in the circumstances. In part, this is probably because the project is not owned or mainstreamed by government (which has not contributed funding); the administrative energy still remains with NFMV which has difficulties in resourcing a program with the necessary continuity.

\section{References}

Geddes WR (2000) Deuba: a study of a Fijian village. Institute of Pacific Studies, University of the South Pacific, Suva

Hope G, Stevenson J, Southern W (2009) Vegetation histories from the Fijian Islands: alternative records of human impact. In: Clark G, Anderson A (eds) The early prehistory of Fiji. ANUE Press, Canberra, pp 63-86

McClatchey WC, Cox PA (1992) Use of sago palm Metroxylon warburgii in the Polynesian Island, Rotuma. Econ Bot 46:305-309

Morrison C, Rounds I, Watling D (2012) Conservation and management of the endangered Fiji sago palm, Metroxylon vitiense, in Fiji. Environ Manag. doi:10.1007/s00267-012-9836-3

NFMV (2008a) A report on the edible palm heart trade of the Fiji sago palm Metroxylon vitiense. Unpublished report, NatureFiji-MareqetiViti, Suva

NFMV (2008b) Guidelines for the sustainable harvesting of the Fiji sago palm. Unpublished report, NatureFiji- MareqetiViti, Suva 
NFMV (2010) Soga: Fiji sago palm Metroxylon vitiense recovery plan 2010-2015. Unpublished report (2010/06), NatureFiji- MareqetiViti, Suva

NFMV (2012) Fiji sago palm Metroxylon vitiense restoration guidelines. Unpublished report (2012/06), NatureFiji-MareqetiViti, Suva

Rounds I (2007) Conservation, management and ethnobotany of sago (Metroxylon vitiense) in South East Viti Levu, Fiji Islands. MSc. Thesis, University of the South Pacific, Fiji

Seemann B (1862) Viti: an account of a government mission to Vitian or Fijian Islands in the years 1860-61. Colonial History Series No. 85 Cambridge. (Reprinted 1973)

Watling D (2005) Palms of the Fiji Islands. Environmental Consultants Fiji Ltd, Suva

Watling D, Chape SA (1992) Fiji: National State of the Environment Report. IUCN Consultants Government of Fiji, Suva

Open Access This chapter is licensed under the terms of the Creative Commons Attribution 4.0 International License (http://creativecommons.org/licenses/by/4.0/), which permits use, sharing, adaptation, distribution and reproduction in any medium or format, as long as you give appropriate credit to the original author(s) and the source, provide a link to the Creative Commons license and indicate if changes were made.

The images or other third party material in this chapter are included in the chapter's Creative Commons license, unless indicated otherwise in a credit line to the material. If material is not included in the chapter's Creative Commons license and your intended use is not permitted by statutory regulation or exceeds the permitted use, you will need to obtain permission directly from the copyright holder. 